\title{
MARIA NIEDZIÓŁKA
}

University of Warsaw, Poland

\section{The role of Józefów municipality in assuring the realization of the right to leisure}

Abstract: According to the Maslow's hierarchy of needs the need to rest is a basic need and it should be the public obligation to ensure its proper realization. Are cities they live able to answer for that need? The article is based on a case study of the Józefów municipality (in Otwock county) and focused on cycling infrastructure. The purpose of this article is to explore and to analyse whether the authorities of the city fulfill their obligation to enable residents to exercise their right to rest on the example of cycling tourism. The work indicates the essence and importance of cycling tourism, taking into account its social importance.

The article is theoretical when it concerns the legal basis of the right to rest, analytical while analysing statistical data and strategic documents of the local community and empirical.

Keywords: need to rest, cycling infrastructure, Józefów, Otwock.

\section{Introduction}

Depression, chronic stress, obesity are just examples of civilization diseases from which modern society suffered before but coronavirus crisis has only deepened them. For health and social reasons after the lock-down, people desire an open-air and an active rest. 
Training sport, including cycling, plays an important role in social life. Forms of tourism related to the broadly understood physical activity and sport are of interest to many authors both in Poland and abroad. Tourism, sport are forms of free-time activities which are vital for people's well-being.

\section{Characteristic of the Józefów municipality}

The city of Józefów is located in the Mazowieckie voivodeship, in the Otwock County. It neighbors Warsaw to the north, Otwock to the south, Vistula to the west, and Wiązowna municipality to the west. The city covers an area of almost twenty four square kilometers with small land denivelations due to its location in the Masovian Lowland. The city has great natural values, as evidenced by three reserves and a landscape park created on its territory ${ }^{1}$ :

1. Świder Nature Reserve - protecting the unique landscape of the Świder valley,

2. Zawadowskie Islands Nature Reserve - protecting the Vistula ecosystems,

3. The Świderskie Islands Nature Reserve - protecting the estuary, 4. Mazowiecki Landscape Park "Czesław Łaszek".

Historically, Józefów was inhabited by Jewish people who came to these areas during the holiday season. The favourable microclimate of pine forests was conducive to the treatment of upper airway, which is why there were so many sanatoriums in the surrounding forests. It is estimated that in the interwar's summer

${ }^{1}$ Barbachowska B. (2013) Uwarunkowania społeczno-gospodarcze rozwoju powiatu otwockiego, Józefów, p. 61-62. 
there were more patients and vacationers than residents ${ }^{2}$. This is due to the construction of two railway routes. The first one is Nadwiślańska Kolej Żelazna (the Vistula Railway) in 1877 and later the narrow-gauge railway (the so-called Jablonowska railway) in $1912^{3}$. The Vistula Railway is the route connecting Mława with Kowel, which you could get from Volhynia up to Prussia, and the so-called Jabłonna railway connected Jabłonna with Karczew. The Vistula Railway is currently the most important communication route of the city, because it connects Józefów with the capital and cities such as Otwock, Pilawa, Deblin etc.

From 1925 Józefów belonged to the Letnisko Falenica Commune, but in 1951 as a result of the Warsaw's amalgamation the commune was divided into a part incorporated to Warsaw and the new one: Józefów municipality. In 1962, Józefów received city rights, in accordance with polish legal provisions, it became an urban type municipality (the boundaries of the municipality coincide with the city ones).

According to the data derived from the Statistics Poland (as at 31 December 2018), the population of Józefów is 20605 people, and the population density is 862 people per $1 \mathrm{~km} 2$ (this value is comparable to the population density of the Wawer- Warsaw's city borough). People who actively spend their free time are in the 15-49 age group, although nowadays it cannot be forgotten about the increasingly active seniors in the 50-69 age group. Both these groups covered $45.45 \%$ and $24.91 \%$ of the entire population of the Józefów municipality.

2 www.jozefow.pl/page/840,historia.html (23.12.2019)

3 Lewandowski R. (2009) Świdermajer XXI wieku, issue 8, Józefów 2009, p. 10. 
Figure 1

The age structure of Józefów's inhabitants

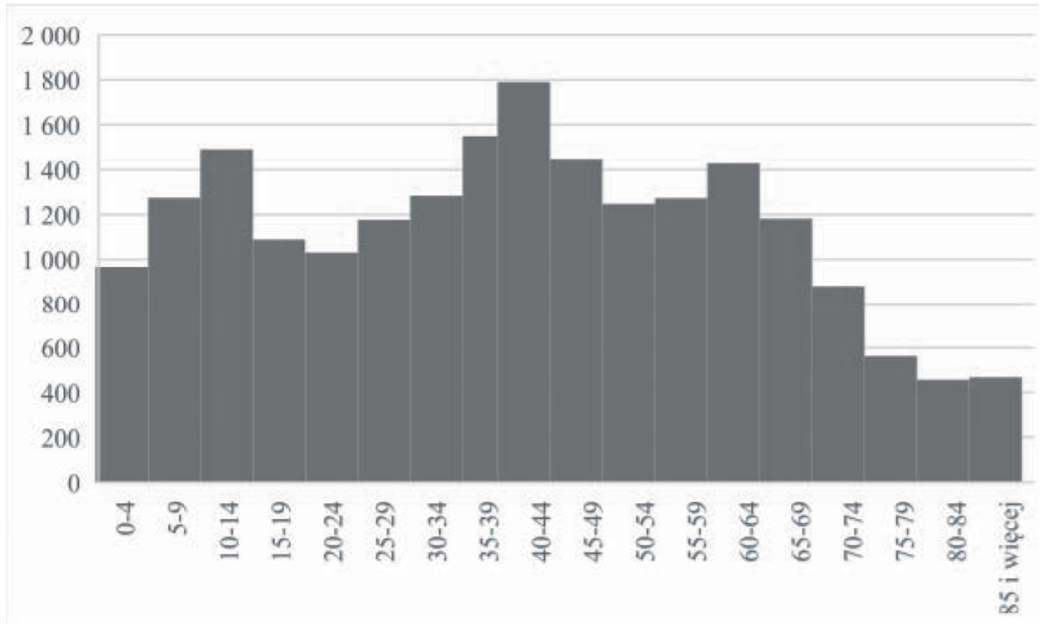

Source: own study based on the Local Data Bank of the Statistics Poland.

\section{The right to leisure}

In The Universal Declaration of Human Rights (adopted in 1948) the right to rest is provided in the 24 Article. It means that everybody has the right to the reasonable working hours and leisure time. The content of this article is repeated and elaborated on in Article 30 of the Convention on the Rights of Persons with Disabilities (2008) or in art 7 point D of the International Covenant on Economic, Social and Cultural Rights (1966). However, we can infer from the content of this provision that vacation and leisure are more than just restrictions on working hours and paid holidays. It is also ensuring the possibility of implementation this right. ${ }^{4}$ In the European Union, legislation emphasizes the importance

${ }^{4}$ See also: Florek I. (2019) Tourism as a carrier of human rights values, Warszawa, pp. 465-476. 
of the right-personal life balance, which is intended to be helpful and perhaps even a guarantee of a better standard of living for the inhabitants. The EU Working Time Directive (2003/88 /EC) provides the appropriate regulatory framework for working time and the right to rest. While the main aim of this directive is to protect workers' health and safety, the duration and organization of work have an impact on the work-life balance of workersThe directive establishes a legal framework that sets a maximum working week of 48 hours, including overtime. The reference period for calculating the average working time should not exceed four months, but may be extended to six months. Under certain conditions (e.g. if there is a collective agreement with relevant provisions), the duration may be extended to one year. The Working Time Directive also provides for minimum periods of consecutive daily rest (11 hours) and weekly rest (35 hours). The European Union has also launched the Work-Life Balance Directive (EU / 2019/1158), which was adopted in June 2019 and is to be implemented by Member States within three years. The directive extends the existing right to demand "flexible working arrangements" to all working parents of children up to eight years of age and to all carers. Workers exercising this right should be protected against discrimination or less favorable treatment on the basis of parentage. ${ }^{5}$

These regulations at the European level emphasize the importance of the balance between professional work and private life, because, as specialists in the field of human resources management increasingly point out, this balance is not only needed by an employee to rest, but also affects their productivity at work. ${ }^{6}$

5 Piwowarska K. (2020) Unijny raport o równowadze między pracą a życiem prywatnym w cyfrowej organizacji pracy, legalis.pl [access: 15.08.2020]

6 Szejniuk, A. (2014). Równowaga praca - życie osobiste. Journal of Modern Science, 21(2), pp. 313-326. 
In Polish law, the right to rest is not indicated expressis verbis, but it can be derived from the provisions of Art. $66 \mathrm{sec} .2$ of the Constitution. However, the authors point to such a law in the doctrine. ${ }^{7}$

In the case of the city of Józefów, which is referred to as the "bedroom of Warsaw", ie the city where people working in Warsaw live, the city authorities should try to organize recreation places after work or at weekends. Bicycle tourism, dynamically developing recently (The increase in interest is visible in the demand for bicycle tourist trips. In the last few years, we have observed an increase in the number of companies organizing such trips. In 2011, there were 5-8 such companies in Poland. Currently, this number is oscillates around 40 . To this should be added associations, clubs and informal groups, organizing bicycle tourist trips $^{8}$ ) faces problems, mainly due to insufficient infrastructure. ${ }^{9}$

\section{The cycling infrastructure in Józefów}

According to the city's development strategy (made by the company MM Marketing i Innowacje) for 2016- 2025, in 2025 Józefów wishes to be perceived as a "city of creativity, rest

7 Chmaj M. (2008) Wolności i prawa człowieka w Konstytucji Rzeczypospolitej Polskiej, Warszawa, pp. 165-167.

8 Polska Organizacja Turystyczna 92019) Raport: Analiza Podaży Turystyki Rowerowej w Polsce 2019 https://www.pot.gov.pl/attachments/article/1804/ Analiza\%20poda\%C5\%BCy\%20turystyki\%20rowerowej\%202019.pdf [access: 15.08.2020].

9 See also: Dębowska-Mróz M., Ferensztain-Galardos E., Krajewska R., Rogowski A. (2018) Turystyka Rowerowa Jako Forma Turystyki Aktywnej Na Przykładzie Gminy Miasta Radomia, Biuletyn KPZK PAN,

Komitet Przestrzennego Zagospodarowania Kraju Polskiej Akademii Nauk, Zeszyt 269, rok 2018, pp. 103-128 
and health"10. For this purpose, four strategic objectives were formulated along with examples of planned activities. The right to leisure is interwoven throughout all objectives of the strategy. However, it is best represented by points:

- Operational goal 1.2: Ensuring the diversity of the city's sports and recreational offer

- Operational goal 1.3: Development of innovations in culture and leisure activities by creating various cultural offers

- Operational goal 1.4: Increasing the local community activism by enabling personal and professional development

- Operational goal 3.2: Creation and implementation of a comprehensive system of environmental protection and improvement of the aesthetics of the City ${ }^{11}$.

The municipality constantly invests in the development of bicycle infrastructure. In 2011-2018 the city has invested in another $7.4 \mathrm{~km}$ of bicycle routes, which was an increase of $162.7 \%$, and at the end of 2018 there were $19.2 \mathrm{~km}$ of completed routes for cyclists in Józefów so per each 1 square kilometer of the city area there is statistically $0.8 \mathrm{~km}$ of a bicycle path.

In the presented period of 2011-2018 there were years without an increase of bicycle paths in the city, these are the years: 2012, 2014, 2016, 2017. However, the trend is positive: in $20132.4 \mathrm{~km}$ of bicycle paths were built, in 2015 another $2.5 \mathrm{~km}$ and in 2018 another $2.5 \mathrm{~km}$ were added.

In the western part of the city, a coherent series of bicycle paths was created a larger loop with an inner axis and a smaller loop closer to the Vistula. The common part of both loops is

10 Strategia Rozwoju Miasta Józefowa na lata 2016-2025, Józefów 2016, p. 15.

11 Ibid., p.17-19. 
a fragment of Wawerska Street from the Tesco grocery store to the intersection with Graniczna Street, where a private university is located, and primary school No. 2 (with a skate park, a road traffic town, a playground and a pitch). The larger loop is connected with the smaller one, the main advantage of which is the nearby Vistula with green areas, which are the targets of recreational bicycle trips. Along the provincial road No. 801 there are barriers to increase the safety of cyclists. The listed main cycle routes are linked to numerous other routes cycling, thus creating a network of infrastructure-friendly connections cyclists.

Figure 2

The length of cycle routes over the years in the Józefów municipality

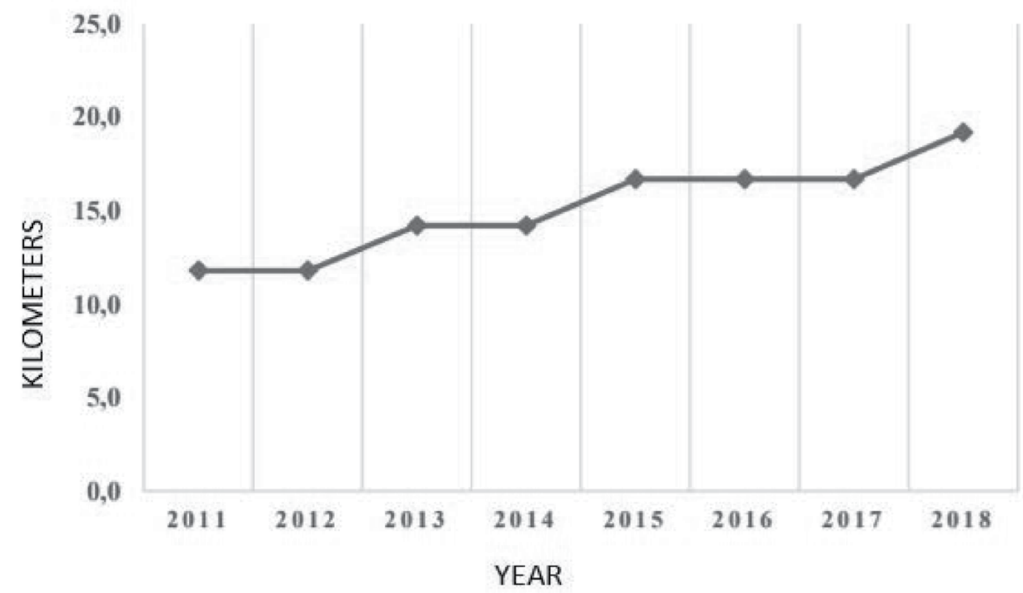

Source: own study based on the Local Data Bank of the Statistics Poland.

Since May 2017, the City of Józefów has been one of the six beneficiaries of the EU program the Integrated Territorial Investments of the Warsaw Functional Area (in abbreviated form ITI) within which $49.12 \mathrm{~km}$ of bicycle routes and $15.17 \mathrm{~km}$ of 
pavements are built around the capital city. The project is called "Let's choose a bicycle - Partnership for the development of lowemission communication WOF” („Wybierzmy rower - Partnerstwo dla rozwoju komunikacji niskoemisyjnej WOF"), and its total value in the area of six municipalities is $40281635,36 \mathrm{PLN}^{12}$. The main goal of the project is to improve air quality by reducing the share of road transport in favor of bicycle transport, which will reduce the emission of harmful substances into the atmosphere ${ }^{13}$. The goal is achieved through the construction of bicycle routes in the surrounding municipalities: Halinów, Józefów, Karczew, Otwock, Sulejówek and Wiązowna, and the leader of the entire project is the City of Józefów. According to the authors of the project, the newly created bicycle paths are to serve not only recreational purposes, but are to constitute transport corridors that will complement the existing transport system in the municipalities. By reducing the number of individual cars, road safety will be improved and the problem of congestion will be reduced ${ }^{14}$. There are $45.58 \mathrm{~km}$ of bicycle paths created; $3.54 \mathrm{~km}$ of walking cycle paths and 15, $17 \mathrm{~km}$ of pavements.

Each municipality is responsible for the implementation of the project in its area, thus the investment in Józefów is planned along the following streets: Nadwiślańska, Graniczna, Skorupki, Wyszyńskiego, Sikorskiego, Piłsudskiego, Jarosławska ${ }^{15}$. Based on data from the city council, all planned investments were

12 www.jozefow.pl/page/1244,projekt-wybierzmy-rower---partnerstwo-dla-rozwoju-komunikacji-niskoemisyjnej-wof.html (24.09.2019)

13 www.jozefow.pl/page/1256,cel-ogolny-oraz-cele-szczegolowe.html (24.09.2019)

14 www.jozefow.pl/page/1246,cel-projektu-i-uzasadnienie-potrzeb-jego-realizacji.html (24.09.2019)

15 www.jozefow.pl/page/1245,zadania-z-podzialem-na-gminy.html (24.09.2019) 
completed by the end of October $2018^{16}$, and the entire project was completed on 30 September 2019.

Figure 3

The length and value of bicycle and walking paths within the Integrated Territorial Investments of the Warsaw Functional Area

\begin{tabular}{|c|c|c|}
\hline Shareholder & $\begin{array}{c}\text { The length of bicycle paths } \\
\text { and walking cycle paths }\end{array}$ & Project value \\
\hline Halinów & $12,00 \mathrm{~km}$ & 6647089,00 PLN \\
\hline Józefów & $8,61 \mathrm{~km}$ & 7355131,84 PLN \\
\hline Karczew & $4,03 \mathrm{~km}$ & 2520390,52 PLN \\
\hline Otwock & $8,24 \mathrm{~km}$ & 9073714,27 PLN \\
\hline Sulejówek & $5,88 \mathrm{~km}$ & 7469803,88 PLN \\
\hline Wiązowna & $10,36 \mathrm{~km}$ & 7215505,85 PLN \\
\hline Sum & $49,12 \mathrm{~km}$ & 40281635,36 PLN \\
\hline
\end{tabular}

source: own study based on: www.jozefow.pl/page/1245,zadania-z-podzialem-nagminy.html (24.09.2019)

In September 2017, the Road Traffic Town was opened in Józefów, where children learn the rules of road safety the investment cost the city 600709,37 PLN. This place is ${ }^{17}$ :

fenced,

$\checkmark$ free

- open from 8.00 to dusk (from spring to autumn),

- available for children equipped with helmets and under supervision,

- for children over 3 years of age.

16 www.jozefow.pl/page/1294,2018-rok.html (24.09.2019)

17 Regulations for using the Road Traffic Town, available online or before entering on the fence 
Figure 4

The Road Traffic Tow

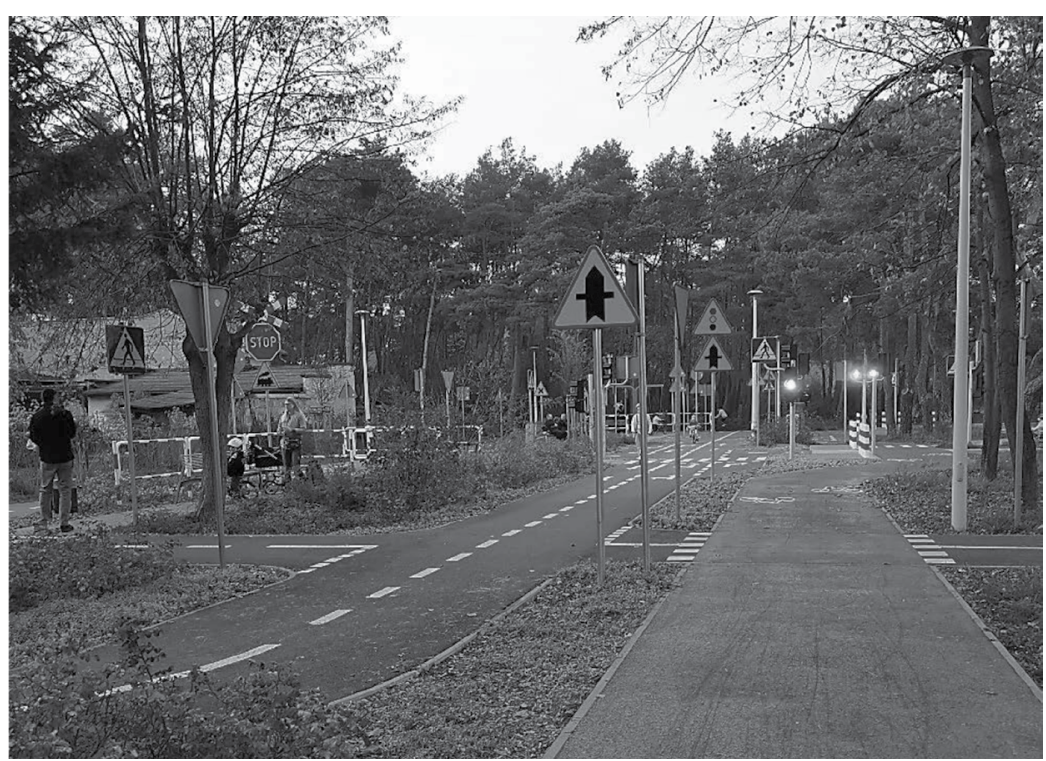

source: the own photography

The Road Traffic Town is located near a primary school, a playground and a skate park, thus creating the opportunity for residents to actively relax in the fresh air. Apart from basic elements such as: asphalt road, bicycle path, pavement and road signs, the town also includes synchronized traffic lights that change every few seconds and a small playground with a swing. Due to the railway line Warsaw-Deblin and the consequent potential danger for cyclists, the Road Traffic Town stages the crossing through the railway line. In addition, the city has purchased 20 bicycles, on which students of Józefów primary schools pass the bicycle license tests and are trained by the municipal police in road traffic regulations ${ }^{18}$.

18 www.iotwock.info/artykul/miasteczko-ruchu-drogowego/482993 (29.11.2019) 
Cyclists in Józefów can use the self-service bicycle facility, which is located at the intersection of Graniczna and Wawerska streets. It enables to place the bicycle vertically and is equipped with a set of wrenches, screwdrivers and a manual pump.

\section{Conclusions}

In 2018 the Józefów city had a positive birth rate (amounting 1.46) and positive rate of internal and international migrations (respectively 63 and 6 people) which shows the city in a positive light and might evidence that city's care about its inhabitants is effective. The Józefów city is aware of the importance of leisure time in human life. Therefore, through following infrastructure investments, it supports, enables and encourages residents to spend their free time in an active way. It brings health benefits to the people and bicycles are an alternative mean of transport which reduces transport congestion, relieves road infrastructure and reduces $\mathrm{CO} 2 \mathrm{emissions} \mathrm{to} \mathrm{the} \mathrm{atmosphere.} \mathrm{Itis} \mathrm{highly} \mathrm{recommended}$ to develop a strategy for building infrastructure common to the neighboring municipalities, so that the bicycle can be used every day as an alternative means of transport (instead of, for example, a car for commuting to work) and as a short-term (or weekend) form of recreation, which requires consistency (convenient connection) of municipal bicycle paths. For the development of sports and recreational infrastructure, it is important to understand the needs of users - groups to which particular types of tourist products are targeted. This approach requires taking into account both types of user groups, understanding their needs and ways of spending time, and then the possibility of introducing products tailored to these expectations, taking into account the city's capabilities. Unfortunately, very often the construction of bicycle 
paths is an "addition" to the road renovation, which significantly increases the chances of obtaining funds for renovation. Since it is a necessary, but also an unwanted addition, it is difficult to expect a well-thought-out, consistent network of bicycle routes.

\section{References:}

BARBACHOWSKA B., Uwarunkowania społeczno-gospodarczego rozwoju powiatu otwockiego, Józefów: Wyższa Szkoła Gospodarki Euroregionalnej, 2013. ISBN 978-83-62753-27-7.

CHMAJ M., Wolności i prawa człowieka w Konstytucji Rzeczypospolitej Polskiej, Warszawa: Wolters Kluwer Polska, 2008. ISBN 978-837526-825-6.

DĘBOWSKA-MRÓZ M., FERENSZTAIN-GALARDOS E., KRAJEWSKA R., ROGOWSKI A.,Turystyka Rowerowa Jako Forma Turystyki Aktywnej Na Przykładzie Gminy Miasta Radomia, Biuletyn KPZK PAN, Komitet Przestrzennego Zagospodarowania Kraju Polskiej Akademii Nauk, Zeszyt 269, 2018.

FLOREK I., Tourism as a carrier of human rights values, W: Współczesne problemy praw człowieka : wybrane aspekty = Contemporary problems of human rights: selected aspects. s. 465-476, Warszawa: Wyższa Szkoła Gospodarki Euroregionalnej, 2019. ISBN 978-838090-670-9.

LEWANDOWSKI R., Świdermajer XXI wieku, issue 8, Józefów: Robert Lewandowski, 2009. ISBN 978-83-9291-300-9.

PIWOWARSKA K., Unijny raport o równowadze między pracą a życiem prywatnym w cyfrowej organizacji pracy, 2020, legalis.pl [access: 15.08.2020]

Polska Organizacja Turystyczna 92019) Raport: Analiza Podaży Turystyki Rowerowej w Polsce 2019 https://www.pot.gov.pl/attachments/ article/1804/Analiza \%20poda\% C5\%BCy\%20turystyki $\% 20$ rowerowej\%202019.pdf [access: 15.08.2020].

Regulations for using the Road Traffic Town, available online or before entering on the fence

Strategia Rozwoju Miasta Józefowa na lata 2016-2025, Józefów 2016. 
SUCH-PYRGIEL, M., Zdrowie i aktywność fizyczna w opinii publicznej na podstawie wybranych raportów z badań CBOS, TNS OBOP i Diagnozy Społecznej, [w:] Michałków I. (red.), Społeczne i rekreacyjno-zdrowotne aspekty edukacji, Wydawnictwo Uczeni Warszawskiej im. Marii Skłodowskiej-Curie, Warszawa, 2013, 349- 361. ISBN 978-83-9287-159-0.

SZEJNIUK, A., Równowaga praca - życie osobiste. Journal of Modern Science, 21(2), 2014.

\section{Netography}

www.iotwock.info/artykul/miasteczko-ruchu-drogowego/482993 (29.11.2019)

www.jozefow.pl/page/1244,projekt-wybierzmy-rower---partnerstwo-dlarozwoju-komunikacji-niskoemisyjnej-wof.html (24.09.2019)

www.jozefow.pl/page/1245,zadania-z-podzialem-na-gminy.html (24.09.2019)

www.jozefow.pl/page/1246,cel-projektu-i-uzasadnienie-potrzeb-jegorealizacji.html (24.09.2019)

www.jozefow.pl/page/1256,cel-ogolny-oraz-cele-szczegolowe.html (24.09.2019)

www.jozefow.pl/page/1294,2018-rok.html (24.09.2019)

www.jozefow.pl/page/840,historia.html (23.12.2019)

\section{List of figures}

Figure 1 The age structure of Józefów's inhabitants

Figure 2 The length of cycle routes over the years in the Józefów municipality

Figure 3 The length and value of bicycle and walking paths within the Integrated Territorial Investments of the Warsaw Functional Area

Figure 4 The Road Traffic Town 